\title{
Dutch Brazil
}

Michiel van Groesen

\author{
This is a post-print version of 'Groesen M. van (2018), Dutch Brazil, Oxford \\ Bibliographies.Classics,' available online at: https://doi.org/10.1093/obo/9780199730414- \\ 0283
}

\section{Introduction}

Dutch Brazil was the most important colony of the West India Company, and constituted the only truly imperial moment of the so-called Dutch Golden Age. In May 1624 a Dutch fleet invaded Salvador de Bahia, the capital of Habsburg Brazil, but surrendered the city to a Luso-Spanish armada eleven months later. The West India Company returned to capture Pernambuco in February 1630, gradually extending their territorial control from Maranhão in the north to Sergipe in the south, and retaining power in Recife until January 1654. The war the Dutch waged in Brazil, first against Habsburg Spain and then against the restored Portuguese monarchy, was the main geopolitical conflict in the Atlantic world in the first half of the 17th century. Despite its importance, Dutch Brazil is often regarded by historians of the Atlantic world as an incongruity. The Dutch Atlantic is considered an anomaly among more durable empires, while Brazil occupies a distinct position in scholarship on South America. Yet the implications of the northern European infiltration into the Iberian sphere of influence were profound. The establishment of the colony undermined the notion of Habsburg supremacy in Latin America and increased Luso-Spanish tensions at home. It brought a hitherto unimaginable (albeit often mythologized) form of religious tolerance to the Americas, and created a multicultural society in which Protestant soldiers, Catholic sugar planters, African slaves, and Sephardic Jews all lived alongside the colony's various native groups. The charismatic governor Johan Maurits of Nassau-Siegen, who ruled in Recife from 1637 to 1644, financed prestigious scientific and artistic studies of the tropics and imported to Pernambuco his European notions of cosmopolitan court culture. The possession of northeast Brazil enabled the West India Company to transform the sugar market, and after conquering Portugal's African strongholds in Guinea and Angola, it looked set to dominate the transatlantic slave trade too. A revolt from Portuguese sugar planters in June 1645, however, supported openly from Bahia and behind the scenes also from Lisbon, heralded the colony's downfall, effectively sealed by two military encounters at Guararapes in 1648 and 1649 which the Dutch both narrowly lost. The fall of Recife, exceptionally well-fortified against an invading naval force, was postponed for another four and a half years. A lack of support from the political elite in the Dutch Republic, amid accusations of corruption, meant that the West India Company would abandon Brazil and shift their focus from empire building to commerce and trade in the Caribbean.

\section{General Overviews}

There are two classic 20th-century overviews of Dutch Brazil that are still being used by historians today. Gonsalves de Mello 1947 is a Braudellian, occasionally slightly nostalgic account of the influence of the Dutch occupation on Pernambucan society, based mainly on archival material in The Hague. Boxer 1957 offers a typically forceful narrative of political and military developments in Brazil, placed in the context of the global war between the Dutch Republic, Portugal, and the Habsburg monarchy. Both authors write glowingly about the role of Johan Maurits of Nassau-Siegen, to whom Van den Boogaart 1979, an influential collection of essays including a contribution by the great Brazilian sociologist Gilberto Freyre, is entirely dedicated. Three recent works have opted for a somewhat broader perspective, reconfiguring the position of Dutch Brazil within Atlantic history. The essays in Van Groesen 2014 focus on the colony's multiple legacies from the restoration of Portuguese rule until after Brazilian independence, with specific attention devoted to the emergence of regional and national mythologies. Klooster 2016, rich in detail, emphasizes the crucial role of Brazil in the concerted Dutch policy of anti-Spanish aggression, focusing mainly on trade and the ravages of war in the Atlantic world, while Van Groesen 2017, using printed sources from across early modern Europe, argues that the Amsterdam media turned Dutch Brazil into a major news story in the 17th century, which gave rise to a "public" Atlantic world.

\section{- Boxer, Charles R. The Dutch in Brazil, 1624-1654. Oxford: Clarendon, 1957.}

A traditional account of Dutch Brazil, detailing the rise and fall of the colony. Almost exclusively focused on political and military events, it remains a classic. Still a very good place to start for those unfamiliar with the topic. Reprinted multiple times and translated into Portuguese (Os Holandeses no Brasil, 2004) and Dutch (De Nederlanders in Brazilië, 1993). 
- Gonsalves de Mello, Jose Antonio. Tempo dos Flamengos: Influência da ocupação holandesa na vida e na cultura do norte do Brasil. Rio de Janeiro, Brazil: Livraria José Olympio, 1947.

The first modern overview of Dutch Brazil that has stood the test of time. Occasionally succumbs to regional mythologizing of the colony, but its discussions of Dutch influence on life in Recife and on the sugar plantations of Pernambuco remain useful and often revealing. Translated into Dutch in 2001, as Nederlanders in Brazilië.

- Klooster, Wim. The Dutch Moment: War, Trade, and Settlement in the Seventeenth-Century Atlantic World. Ithaca, NY: Cornell University Press, 2016.

Broad overview of the West India Company's policies and achievements in the Atlantic world in the period between 1620 and 1670, with considerable attention on Dutch Brazil. A good introduction for undergraduates and graduates interested in the idiosyncratic Dutch Atlantic and the geopolitical importance of Dutch Brazil.

- van den Boogaart, Ernst, et al., eds. Johan Maurits van Nassau-Siegen, 1604-1679: A Humanist Prince in Europe and Brazil. The Hague: Johan Maurits van Nassau Stichting, 1979.

Sharply focused collection of seventeen essays, exploring the achievements of Johan Maurits of Nassau-Siegen as a humanist or even proto-enlightened ruler, mainly in Brazil. Covers a broad range of topics, including art, architecture, science, cartography, and indigenous alliances.

- $\quad$ van Groesen, Michiel, ed. The Legacy of Dutch Brazil. New York: Cambridge University Press, 2014.

Twelve essays, bookended by an extensive introduction and an even longer historiographical epilogue, discuss the longterm impact of Dutch Brazil on Europe, Africa, and the Americas, taking scholarship on the colony beyond national historiographies. Divided into three sections dealing with geopolitical, cultural, and national legacies respectively.

- $\quad$ van Groesen, Michiel. Amsterdam's Atlantic: Print Culture and the Making of Dutch Brazil. Philadelphia: University of Pennsylvania Press, 2017.

Synthetic study of Dutch Brazil, focusing on the flow of information between the Americas and Europe and on public debate. Demonstrates the relevance of Atlantic history for the Dutch Republic and vice versa by arguing that the "Amsterdamnification" of Dutch Brazil, triggered by publishers with a keen eye for commerce, ultimately led the authorities to withdraw their support for the colony.

\section{Historiography and Primary Sources}

Scholarship on Dutch Brazil, especially in Brazil, has been characterized by persistent nativist mythologies from the 19th century onward. As a result, as Rubiés 2014 explains in great detail, the story of Dutch Brazil remains relevant in Brazil today for two reasons: first, because the belief long persisted that opposition to the Dutch regime brought together all Brazilian ethnicities in a proto-national quest for liberty; and second, because the Dutch interlude embodied a missed junction to modernity in the shape of free trade and religious toleration. In the Netherlands, in stark contrast, the memory of the negligent loss of Brazil was so painful that it generated little scholarship. Dutch historians who did write on Brazil, in the 19th and 20th centuries, focused on the supposedly benevolent reign of Johan Maurits (Van den Boogaart 2012), often informed by textual sources published under the auspices of the count himself. Klooster and Emmer 1999, by coining the notion of "expansion without empire," inadvertently explains why as the only imperial moment in Dutch (Atlantic) history, Dutch Brazil has long received comparatively little attention in the Netherlands. Primary material includes surviving manuscript sources from the West India Company (Archives of the "Old" West India Company (OWIC), 1621-1674) and printed sources in the form of pamphlets (Dutch Pamphlets, 1486-1853: The Knuttel Collection). Wiesebron, et al. 20042013 is a comprehensive five-volume inventory of the remaining archival sources in the Netherlands. Galindo and Hulsman 2005 is less extensive, but contains interesting observations on the formation of various archival collections. 
- $\quad$ Archives of the "Old" West India Company (OWIC), 1621-1674. The Hague: National Archives.

The archives of the West India Company were decimated in the 19th century, but the documents which have survivedmainly those which used to be preserved in Middelburg, Zeeland, including minutes of the meetings of the Zeeland directors and overgekomen brieven en papieren from Dutch Brazil-have all been digitized by the Nationaal Archief in recent years.

- Dutch Pamphlets, 1486-1853: The Knuttel Collection. The Hague: National Library of the Netherlands.

The Knuttel Collection of printed pamphlets, assembled in the late 19th and early 20th century, has now been fully digitized, although unfortunately behind a paywall. The collection contains many dozens of pamphlets related to Dutch Brazil as the colony generated extensive public debate in the Dutch Golden Age. Available online by subscription.

- Galindo, Marcos, and Lodewijk Hulsman. Guia de Fontes para a história do Brasil Holandês. Recife, Brazil: Massangana, 2005.

Handsome guide to visual, printed, and handwritten sources on the history of Dutch Brazil. Particularly useful because of its explanation of how the archives were formed, and why certain documents survived and others did not.

- Klooster, Wim, and Piet Emmer. "The Dutch Atlantic, 1600-1800: Expansion Without Empire." Itinerario 23.2 (1999): 48-69.

DOI: $10.1017 /$ S0165115300024761

"Expansion without empire" became a catchphrase for scholars working on the idiosyncratic Dutch presence in the early modern Atlantic world. The authors argue that as settlement colonies in the 17th century were ultimately unprofitable because they suffered from a lack of migrants, the Dutch subsequently decided to focus on trade and commerce instead.

- $\quad$ Rubiés, Joan-Pau. “Mythologies of Dutch Brazil.” In The Legacy of Dutch Brazil. Edited by Michiel van Groesen, 284317. New York: Cambridge University Press, 2014.

DOI: 10.1017/СBO9781107447776.017

Erudite historiographical examination of 19th- and 20th-century myths and counter-myths. Rubiés emphasizes that it is precisely because of this array of mythologizing that Dutch Brazil continues to matter today, especially to Brazilians (and even more so in the northeast).

- Wiesebron, Marianne, ed. Brazilië in de Nederlandse archieven (1624-1654)/O Brasil em arquivos neerlandeses (1624-1654). 5 vols. Leiden, The Netherlands: Leiden University Press, 2004-2013.

Bilingual inventory of all the archival material related to Brazil in the Netherlands, with short introductory essays in Dutch and Portuguese (Volume 1). Contains lists of documents in the Nationaal Archief (OWIC), but also in the less accessible Koninklijk Huisarchief, where the material on Dutch Brazil still awaits digitization.

- van den Boogaart, Ernst. "As perspectivas da Holanda e do Brasil do 'Tempo dos Flamengos'." In Brasil Holandês: História, memória e patrimônio compartilhado. Edited by Hugo Coelho Vieira, Nara Neves Pires Galvão, and Leonardo Dantas Silva, 47-63. São Paulo, Brazil: Alameda, 2012.

Historiographical essay juxtaposing what Dutch Brazil has meant to scholars in the Netherlands and Brazil. Explains the rise to prominence of Johan Maurits in 19th-century Dutch historiography as part of a carefully constructed national identity around the House of Orange-Nassau. 


\section{Printed, Edited, and Translated Sources}

De Laet 1931-1937 and Van Baerle 2011 are arguably the two most important narrative sources written in the Dutch Republic related to Dutch Brazil, the former written from the viewpoint of the West India Company, the latter from the perspective of Johan Maurits of Nassau-Siegen. Both views were increasingly at odds with each other. Although De Laet 2008 is attributed by the editors to the Leiden humanist, this is by no means certain. The document was probably composed to introduce Dutch Brazil to Johan Maurits, and can be read as a mid-1630s status report on the colony, written after Portuguese resistance (described in Coelho 1982) had finally been broken. Most eyewitness accounts of Dutch Brazil have been written by German soldiers: Aldenburgk 1930 contains two very interesting accounts focusing on the 1620 s and 1630s, while Hansen Hajstrup 1995 is a breathtakingly honest assessment of the demise of the colony in the late 1640s. Moreau 1651 is an influential printed version of the many misgivings in the later years of Dutch Brazil. Describing the same period, Calado 2004 offers a close-up view of the uprising from a Luso-Brazilian perspective. Ferrão and Monteiro Soares 1993-2002 focuses mainly on visual evidence of Dutch Brazil, although it too contains editions of handwritten accounts. Gonsalves de Mello 1986 provides translations into Portuguese of several administrative accounts of the colony, while Cabral de Mello 2010 retells the entire chronological story of Dutch Brazil based on translated and edited primary texts.

- $\quad$ Aldenburgk, Johann Gregor. Reise nach Brasilien, 1623-1626. Edited by Samuel P. L'Honoré Naber. The Hague: Nijhoff, 1930.

Candid and very detailed account of a German soldier participating in the Dutch conquest of Salvador in 1624-1625. The same volume contains two other accounts of German soldiers in Dutch Brazil, another very rich one by Ambrosius Richshoffer (1629-1632), and a very short and uneventful journal by Michael Hemmersam who also visited West Africa (1639-1645).

\section{- Cabral de Mello, Evaldo, ed. O Brasil Holandês. São Paulo, Brazil: Companhia das Letras, 2010.}

Edition of primary sources, introduced, translated, and contextualized by the leading Brazilian specialist on the colony today. With considerable attention on the reign of Johan Maurits and the planters' revolt.

- Calado, Manóel. O Valeroso Lucideno e Triumfo da Liberdade na Restauração de Pernambuco. 2 vols. Edited by Leonardo Dantas Silva. Recife, Brazil: CEPE, 2004.

Eyewitness account of the revolt of Portuguese sugar planters against the Dutch regime in Pernambuco, first published in Lisbon in 1648. Strongly biased in favor of the twin causes of Restoration Portugal and Roman Catholicism, the friar's narrative is nevertheless a unique close-up view of the social dynamics behind the rebellion.

- Coelho, Duarte de Albuquerque. Memórias Diárias da Guerra do Brasil. Recife, Brazil: Fundação de Cultura Cidade do Recife, 1982.

Revealing eyewitness account of the guerrilla war against the Dutch invaders in Pernambuco in the early 1630s. Offers a clear view on why the West India Company had great difficulty in rapidly appropriating the province.

- de Laet, Johannes. Iaerlijck Verhael van de verrichtinghen der geoctroyeerde West-Indische Compagnie in derthien boecken (1624-1636). 4 vols. Edited by S. P. L'Honoré Naber and J. C. M. Warnsinck. Werken van de LinschotenVereeniging 34, 35, 37, and 40. The Hague: Martinus Nijhoff, 1931-1937.

Four-volume corporate history describing the annual achievements of the West India Company, written by a respected Leiden humanist who was a board member of the company's Amsterdam chamber. Probably the most important source for the early history of Dutch Brazil, with a strong emphasis on policymaking, shipping, and naval battles. De Laet's original work was also translated into Portuguese ("Historia ou annaes dos feitos da Companhia privilegiada das Indias occidentais," Anais da Biblioteca Nacional do RJ, 1916). 
- de Laet, Johannes. Suiker, verfhout \& tabak. Het Braziliaanse handboek van Johannes de Laet, 1637. Edited by Benjamin Teensma. Werken van de Linschoten-Vereeniging 108. Zutphen, The Netherlands: Walburg Pers, 2008.

Transcription of a manuscript in the John Carter Brown Library. Attributed by the editor to Johannes de Laet, although there is no conclusive evidence as to his authorship. The text provides an overview of the situation in Dutch Brazil on the eve of Johan Maurits's departure, and was probably intended for the governor's eyes.

- Ferrão, Cristina, and José Paulo Monteiro Soares, eds. Brasil Holandês. 5 vols. Petropolis, Brazil: Editora Index, 1993-2002.

Valuable series of transcribed, edited, and translated documents related to the cultural history of Dutch Brazil, including travel accounts and (mainly) visual material from the likes of Albert Eckhout and Zacharias Wagner which is difficult to access elsewhere.

- Gonsalves de Mello, Jose Antonio, ed. Fontes para a história do Brasil holandês. 2 vols. Recife, Brazil: CEPE Editora, 1986.

Transcription and translation into Portuguese of several key sources related to the economic and political history of Dutch Brazil by one of the leading scholars in the field.

- Hansen Hajstrup, Peter. Memorial und Jurenal. Edited by Frank Ibold, Jens Jäger, and Detlev Kraack. Neumünster, Germany: Wachholtz Verlag, 1995.

Edition of a private diary of a soldier from northern Germany, in German, who served in Dutch Brazil between 1644 and 1654. Probably the best account of the daily life of military personnel of the West India Company in Brazil: frank, personal, and unpolished, with many valuable details. Recently translated into Portuguese as Viagem ao Brasil (1644-1654) (2016).

- Moreau, Pierre. Histoire des derniers troubles du Brésil entre les Hollandois et les Portugais. Paris: Augustin Courbe, 1651.

Written by a French administrator in the service of the West India Company, this work is highly critical of Dutch policy and conduct in Brazil. Much of the account cannot be corroborated by other sources. Almost instantly translated into Dutch, as Klare en waarachtige beschryving van de leste beroerten en afval der Portugezen in Brasil (Amsterdam, 1652), Moreau's account further eroded support for Dutch Brazil in the Dutch Republic.

- van Baerle, Casper. The History of Brazil under the Governorship of Count Johan Maurits of Nassau, 1636-1644.

Edited and translated by Blanche T. van Berckel Ebeling-Koning. Gainesville: University Press of Florida, 2011.

Good English translation of perhaps the key contemporary text on Dutch Brazil, Casper Barlaeus's panegyric on the rule of Johan Maurits, which first appeared in Latin in 1647. The translator's extensive introduction to the text is a piece of meticulous scholarship too, and provides the best examination of Barlaeus's contribution to Johan Maurits' self-image to date.

\section{The West India Company and Dutch Brazil}

Schmidt 2001, a strong and well-written study, argues very forcefully that it was the Black Legend of Spanish "tyranny" which formed the intellectual background to Dutch military activities in the Atlantic world. The foundation of the West India Company in 1621 and its policymaking until its bankruptcy in 1674 are the subject of Den Heijer 1994 the only modern survey of the company's history. In Den Heijer 2005 the same author elaborates on the financial aspects of the joint-stock companies in the Dutch Republic, a key contribution to our understanding of political debates in relation to Dutch Brazil. Israel 1982 embeds the evolving storyline of Dutch Brazil in the politics of local, provincial, and federal particularism in the Netherlands. Van Groesen 2011 argues that the two Dutch invasions of Brazil in 1624 and 1630 were closely related, and that the period in between should also be considered an integral part of the colony's history. The cartography of Dutch Brazil, mainly but not exclusively produced at the expense of the West India Company, is impressively 
displayed in Den Heijer and Brommer 2011. Miranda 2014 provides a detailed exploration of the daily life of the many thousands of soldiers in the service of the company, an important topic that had been neglected before, while Weststeijn 2012 opens up avenues to a new intellectual history of the Dutch Atlantic world.

- $\quad$ den Heijer, Henk. De geschiedenis van de WIC. 4th rev. ed. Zutphen, The Netherlands: Walburg Pers, 1994.

General introduction to the history of the West India Company, both as a commercial company and a political instrument. Den Heijer discusses not only the First West India Company which went bankrupt in 1674 because of its failure in Brazil, but also the Second West India Company which lasted until 1791. A lucid analysis, with graphs, tables, and maps, which, inexplicably, still awaits translation into English.

- den Heijer, Henk. De geoctrooieerde compagnie: De VOC en WIC als voorlopers van de naamloze vennootschap. Amsterdam: Kluwer, 2005.

Exhaustive examination of the financial side of the Dutch joint-stock companies, with important information on shareholders and directors, corporate culture, and relations between the companies and the political elite. Offers a fullblown comparison of the East and West India Companies, which is rare in Dutch historiography.

- den Heijer, Henk, and Bea Brommer, eds. Comprehensive Atlas of the Dutch West India Company I. Voorburg, The Netherlands: Atlas Maior, 2011.

Hefty tome with reproductions of hundreds of maps of Dutch Brazil and the Atlantic world more broadly, from manuscript sketches to printed maps and lavishly illustrated decorative wall maps. Essential compendium for those interested in the rich visual culture of Dutch Brazil. A second volume deals with Atlantic maps from the 18th century.

- Israel, Jonathan. The Dutch Republic and the Hispanic World, 1606-1661. Oxford: Oxford University Press, 1982.

Arguably Jonathan Israel's best book-length study, providing an excellent overview of the context of the war between the United Provinces and the Habsburg monarchy of which the Dutch attack on Brazil was an important part. Contains a detailed account of the extensive truce negotiations between Spain and the Dutch Republic in the early 1630s, which (twice) failed because of the West India Company's occupation of Pernambuco. Indispensable.

- Miranda, Bruno R. F. Gente de Guerra: Origem, cotidiano e resistência dos soldados do exército da Companhia das Índias Ocidentais no Brasil (1630-1654). Recife, Brazil: Editora da UFPE, 2014.

Published version of a $2011 \mathrm{PhD}$ dissertation the author defended at Leiden University. Emphasizes the social life of soldiers in the service of the West India Company, with details on recruitment, punishment, desertion, treason, and hunger which have received insufficient attention elsewhere.

- Schmidt, Benjamin. Innocence Abroad: The Dutch Imagination and the New World, 1570-1670. Cambridge, UK: Cambridge University Press, 2001.

Inventive work which argues that both the foundation of the West India Company, and its early policy decisions, were driven by the carefully constructed rhetoric of a Dutch-indigenous alliance against a common enemy, Spain. Schmidt continues his exploration of the Dutch imagination of America until after the Westphalian Peace of 1648, hence charting also the downfall of Brazil. Based on a wide variety of textual and visual sources.

- $\quad$ van Groesen, Michiel. "Lessons Learned: The Second Dutch Conquest of Brazil and the Memory of the First." Colonial Latin American Review 20.2 (2011): 167-193.

DOI: 10.1080/10609164.2011.585770

Article focusing on news maps from the period between the Dutch surrender of Salvador in 1625 and the invasion of Pernambuco in 1630, arguing that despite the lack of a territorial presence, these years too should be considered part of the story of Dutch Brazil because of the unwavering ambition of the West India Company to gain a foothold in Portuguese America. 
- Weststeijn, Arthur. "Republican Empire: Colonialism, Commerce and Corruption in the Dutch Golden Age." Renaissance Studies 26.4 (2012): 491-509.

DOI: 10.1111/j.1477-4658.2012.00824.x

Thought-provoking article on the tension between imperial ambitions and republican ideals in the United Provinces, focusing-despite the title-almost exclusively on Dutch Brazil. Provides important background to our understanding of why public support for Brazil eroded in the Dutch Republic.

\section{Sugar}

Merchants from the Low Countries, closely connected to Sephardic Jews operating in the Atlantic world, had been key players in the sugar trade long before the emergence of Dutch Brazil, as Ebert 2008 and Strum 2013 demonstrate in their complementary works. Studnicki-Gizbert 2007 provides the broadest and best approach to Portuguese trading networks in the Atlantic world, with considerable attention for investors and ship's captains from the Low Countries. Poelwijk 2003demonstrates that the infrastructure for sugar refining in Amsterdam was already well-organized before 1630. Schwartz 2004 places the engenhos of Brazil in the context of the Atlantic world and the sugar revolution, while Cabral de Mello 1975 views the rise and fall of Dutch Brazil from the perspective of its main crop. Massing 2007 and de Carvalho Soares 2009 are devoted to the visual culture of sugar plantations in the Atlantic world, with many references to the paintings of Frans Post.

- Cabral de Mello, Evaldo. Olinda Restaurada: guerra e açúcar no Nordeste, 1630-1654. São Paulo, Brazil: Editora da Universidade de São Paulo, 1975.

Influential overview of the rise and fall of Dutch Brazil, with considerable attention in chapters 2 and 3 on the impact of the Dutch presence in Pernambuco on the sugar industry and vice versa. Provides figures of quantities of sugar grown and transported to Europe, and its effect on the share price of the West India Company.

- de Carvalho Soares, Mariza. "Engenho sim, de açúcar nao: 0 engenho de farinha de Frans Post." Varia Historia 25.41 (January/July 2009): 61-83.

Article confronting Frans Post's paintings of engenhos in light of historical evidence, arguing that at least some of Post's compositions depicted manioc mills rather than sugar mills.

- Ebert, Christopher. Between Empires: Brazilian Sugar in the Early Atlantic Economy, 1550-1630. Leiden, The Netherlands: Brill, 2008.

DOI: 10.1163/ej.9789004167681.i-212

Solid economic study with many tables and graphs. Highlights the role individual merchants from the Low Countries played in the transatlantic sugar trade before the emergence of Dutch Brazil, and argues against an imperial or mercantilist understanding of the Atlantic economy.

- Massing, Jean Michel. “From Dutch Brazil to the West Indies: The Paper Image of the Ideal Sugar Plantation.” In Studies in Imagery II: The World Discovered. Edited by Jean Michel Massing, 172-195. London: Pindar, 2007.

Inspirational article discussing images of the sugar industry before, during, and after the period of Dutch rule in Pernambuco. With many iconographic connections between Frans Post's paintings of engenhos and 18th-century English and French representations of plantation life.

- Poelwijk, Arjan. "In dienste vant suyckerbacken": de Amsterdamse suikernijverheid en haar ondernemers, 15801630. Hilversum, The Netherlands: Verloren, 2003.

Socioeconomic study of the guild of sugar refiners in Amsterdam in the decades leading up to the period of Dutch control in Brazil. Shows the explosive growth of the industry in the Dutch Republic after the Fall of Antwerp in 1585. 
- Schwartz, Stuart B. “A Commonwealth within Itself: The Early Brazilian Sugar Industry, 1550-1670." In Tropical Babylons: Sugar and the Making of the Atlantic World, 1450-1680. Edited by Stuart B. Schwartz, 158-200. Chapel Hill: University of North Carolina Press, 2004.

DOI: 10.5149/9780807895627_schwartz.10

Although Schwartz, in his own contribution to an important volume on the sugar revolution, does not focus specifically on the Dutch period, this article provides invaluable contextual information for scholars interested in the impact of Dutch Brazil on the Atlantic trading system.

- Strum, Daniel. The Sugar Trade: Brazil, Portugal, and the Netherlands (1595-1630). Stanford, CA: Stanford University Press, 2013.

Splendidly produced and lavishly illustrated volume on the Atlantic sugar trade on the eve of Dutch Brazil. Should be read in combination with Ebert 2008 for a full grasp of the impact of the trade in sugar, and the role of the Dutch in Atlantic networks pre-1630.

- Studnicki-Gizbert, Daviken. A Nation upon the Ocean Sea: Portugal's Atlantic Diaspora and the Crisis of the Spanish Empire, 1492-1640. Oxford: Oxford University Press, 2007.

DOI: 10.1093/acprof:oso/9780195175691.001.0001

Important monograph on the trading networks of the Portuguese "nation," including New Christians and Jews, in the Atlantic world during the Union of the Crowns. Demonstrates the significance of connections between Brazil and merchants from the Low Countries both before and during the early years of Dutch rule in Recife.

\section{The Indigenous Population}

Already before the arrival of the Dutch in Pernambuco, the native population had been decimated by the effects of the Columbian exchange. Throughout the 16th century, the image of indigenous Brazilians in the Low Countries was a stereotypical one, invariably associated with cannibalism. Yet emerging geopolitical interest in Brazil brought along the narrative of native Americans as potential allies-a narrative which continued to be important throughout the period of Dutch Brazil. As Schmidt 2001 points out, the intended alliance with native Americans generated great enthusiasm for Brazil in Dutch society before the foundation of the West India Company. The reality of Dutch-indigenous relations in Pernambuco, as Van den Boogaart 1979 shows, was more complicated. Hulsman 2005traces the tragic afterlife of the alliance, after the fall of Recife, when former allies were disappointed with the lack of Dutch efforts to return to Brazil. Hemming 2004, first published in 1978, contextualizes the role of the Dutch in the European encounter with Brazil, while Parker Brienen 2006, in a concise but important study, follows up on Schmidt 2001 by looking at the representations of native Americans made by Albert Eckhout in Dutch Brazil. By far the best and most comprehensive account of Dutchindigenous relations, both in Pernambuco and in the 17th-century Dutch Atlantic world more broadly, is Meuwese 2012, which stays close to the archival records and carefully compares the nature of encounters in various provinces of the shortlived Dutch Atlantic empire.

- Hemming, John. Red Gold: The Conquest of the Brazilian Indians, 1500-1760. London: Pan, 2004 [1978]

Grand narrative of the ways European travelers and colonists gradually turned native American inhabitants of Brazil into their subsidiaries, with some attention for the Dutch contribution to this process in the wake of the encounter between the Dutch and the Tupinamba and Tapuya Indians in the northeast.

- Hulsman, Lodewijk. "Brazilian Indians in the Dutch Republic: The Remonstrances of Antonio Paraupaba to the States General in 1654 and 1656." Itinerario 29.1 (2005): 51-78.

DOI: $10.1017 /$ S0165115300021690

Article focusing on the political attempts of former Brazilian allies of the Dutch to change the decision of the West India Company and the States-General to not give up on Brazil after the surrender of Recife-to no avail. With full-text transcriptions of two remonstrances by Antonio Paraupaba. 
- Meuwese, Mark. Brothers in Arms, Partners in Trade: Dutch-Indigenous Alliances in the Atlantic World, 1595-1674. Leiden, The Netherlands: Brill, 2012.

The most extensive study to date on Dutch-indigenous relations in the Atlantic world, focusing mainly on diplomatic relations and military alliances, at all times staying close to information from the depleted archives of the West India Company in The Hague. Contextualizes Dutch Brazil and compares it to New Netherland and West Africa.

- Parker Brienen, Rebecca. Visions of Savage Paradise: Albert Eckhout, Court Painter in Colonial Dutch Brazil. Amsterdam: Amsterdam University Press, 2006.

Integrates the artistic representations of various native groups in Dutch Brazil within the broader story of European stereotypes, and does a good job of combining pictorial and archival sources in reading Johan Maurits's relationship with the Brazilian inhabitants of Pernambuco.

- Schmidt, Benjamin. Innocence Abroad: The Dutch Imagination and the New World, 1570-1670. Cambridge, UK: Cambridge University Press, 2001.

Emphasizes the role of native Americans and, at times more specifically, native Brazilians in political rhetoric and textual and visual representations of the Dutch Golden Age.

- van den Boogaart, Ernst. "Infernal Allies: The Dutch West India Company and the Tarairiu." In Johan Maurits van Nassau-Siegen, 1604-1679: A Humanist Prince in Europe and Brazil. Edited by Ernst van den Boogaart, et al., 519538. The Hague: Johan Maurits van Nassau Stichting, 1979.

Foundational article discussing the possibilities and problems associated with the desired alliance between the Dutch West India Company and the indigenous rivals of the Tupinamba Indians who had chosen the side of the Habsburgs.

\section{Slave Trade and Slavery}

There is as yet no synthetic study, book-length or otherwise, of life on the plantations of Dutch Brazil-although Puntoni 1999 is an admirable attempt to provide an overview of what has been said by the main eyewitnesses of the colony. This dearth is partly the result of a lack of primary sources, but the omission is glaring all the same. Consequently surveys of slavery in Brazil, like Klein and Luna 2010 and, to a lesser extent, Alencastro 2000, do not pay sufficient attention to the Dutch period. The Dutch involvement in the slave trade is much better documented. Two leading studies, Postma 1990 and Emmer 2006, single out the emergence of Dutch Brazil as the catalyst for Dutch participation in the trade, after initial moral opposition had been overcome, but focus mainly on the later 17th and 18th centuries-for quantitative reasons. According to the most recent assessment of the Trans-Atlantic Slave Trade Database, Dutch ships transported around 600,000 African laborers across the Atlantic Ocean, "only" 32.000 of which made the crossing during the three decades the West India Company ruled in Brazil. The best starting point for the Dutch slave trade in the 1630s and 1640s, therefore, is still Van den Boogaart and Emmer 1979, although its data have since undergone substantial refinement.

- Alencastro, Luiz Felipe de. O Trato dos Viventes: Formação do Brasil no Atlantico Sul - Séculos XVI e XVII. São Paulo, Brazil: Companhia das Letras, 2000.

Monumental study about slavery in 17th-century Brazil, with a focus on the connections between the various sugar captaincies, but mainly Rio de Janeiro, and Angola. Taking a broad thematic approach, it views the Dutch interlude in Pernambuco as a formative period in the making of the slave trade complex in the South Atlantic.

\section{- Emmer, Piet. The Dutch Slave Trade, 1500-1850. New York: Berghahn, 2006.}

Like Postma 1990, this book provides an overview of the Dutch contribution to the transatlantic slave trade. Criticized in the Netherlands for its politically incorrect tone, it nevertheless offers a well-informed and thorough scholarly analysis of the Dutch trade in slaves by a long-term specialist of the topic. Translated from Dutch (De Nederlandse slavenhandel, 1998) 
- $\quad$ Klein, Herbert S., and Francisco Vidal Luna. Slavery in Brazil. New York: Cambridge University Press, 2010.

Authoritative survey of three centuries of slave labor in Brazil. Although Klein and Luna pay only very little attention explicitly to Dutch Brazil, they do offer helpful context on the transfer of slaves from West Africa to Brazil in the 17th century, as well as on plantation life.

- Postma, Johannes. The Dutch in the Atlantic Slave Trade, 1600-1815. Cambridge, UK: Cambridge University Press, 1990.

Even though some of the estimates of numbers of transported and enslaved African laborers have somewhat increased since its appearance in 1990, this book is still the best overall study of the Dutch contribution to the transatlantic slave trade. With many tables, figures, and graphs.

- Puntoni, Pedro. A mísera sorte: A escrivadão africana no Brasil holandês e as guerras do tráfico no Atlântico Sul, 1621-1648. São Paulo, Brazil: Editora Hucitec, 1999.

Concise survey in three parts of the importance of slavery for Dutch Brazil. Parts 1 and 2 offer general context about Dutch trade and slave transports to Brazil pre-1635 (also in ships captured by the West India Company). Part 3 addresses slavery in Dutch Brazil head-on. The author uses some quantitative data, but attempts to integrate narrative sources and visual culture.

- Trans-Atlantic Slave Trade Database.

Indispensable digital tool for a good understanding of the numbers of slaves the Dutch brought to Brazil. At the time of writing, it contains information on thirty-six thousand slaving voyages including some 150 under Dutch flag to Pernambuco between 1635 and 1654. Continues to be updated.

- van den Boogaart, Ernst, and Piet Emmer. "The Dutch Participation in the Atlantic Slave Trade, 1596-1650." In The Uncommon Market: Essays in the Economic History of the Atlantic Slave Trade. Edited by Henry A. Gemery and Jan S. Hogendorn, 353-375. New York: Academic Press, 1979.

Foundational article on the emergence of the Dutch slave trade in both Elmina and Angola, and the only piece of literature explicitly focused on the trade in slaves to Dutch Brazil. Shows the slow emergence of the West India Company's trafficking in slaves in the mid-1630s, and concludes that the trade peaked in the later years of Johan Maurits's reign.

\section{Johan Maurits of Nassau-Siegen}

Johan Maurits of Nassau-Siegen was only thirty-two years old when he was appointed governor-general of Dutch Brazil. After his tenure in Recife from January 1637 to May 1644, he returned to Europe to become stadtholder of Cleves for the Elector of Brandenburg, a position he retained until his death in 1679. He never succeeded in obtaining the more prestigious political positions he craved, despite strategically giving away art and artifacts collected during his time as ruler of northeast Brazil. Van den Boogaart 1979 is still the best point of entry to the life of Johan Maurits, with essays on his youth, his tenure in Brazil, his fondness of art, architecture, and science, and his political career in Europe. Another volume of essays published at the tercentenary of the count's death, So weit der Erdkreis reicht (1979), emphasizes material culture. Many of its essays also remain useful. Brunn 2004 can be read as a short introduction to Johan Maurits's achievements in Brazil, while Cabral de Mello 2006 provides a more detailed yet somewhat lopsided study of the governor's career. Brunn and Neutsch 2008, like the two volumes of essays from 1979, emphasizes the continuity between the court cultures in Recife and Cleves, while de Campos Françozo 2014provides a sharply focused exploration of Johan Maurits's love for and use of material culture. 
- Brunn, Gerhard, ed. Aufbruch in Neue Welten: Johann Moritz von Nassau-Siegen (1604-1679): der Brasilianer. Siegen, Germany: Johann Moritz, 2004.

Concise and richly illustrated volume of essays accompanying an exhibition in Siegen, Germany. Ten short articles collectively provide a comprehensive account of Johan Maurits's life and times, with an emphasis on his role as a patron of the arts. An accessible starting point.

- Brunn, Gerhard, and Cornelius Neutsch, eds. Sein Feld war die Welt: Johann Moritz von Nassau-Siegen (1604-1679). Münster, Germany: Waxmann, 2008.

Collection of fourteen essays which originated in a 2004 conference in Siegen. Most of the articles, all in German, deal with Johan Maurits's tenure in Brazil, and the collection makes a commendable effort to contextualize Dutch Brazil by comparing it to other contemporary achievements in Europe (mainly Germany), Asia, and the Atlantic world.

- Cabral de Mello, Evaldo. Nassau: Governador do Brasil holândes. São Paulo, Brazil: Companhia das Letras, 2006.

First complete biography of Johan Maurits since the mid-20th century. With a strong focus on his tenure as governorgeneral of Dutch Brazil, and only a very brief discussion of the last three decades of the count's career as stadtholder of Cleves.

- de Campos Françozo, Mariana. De Olinda a Holanda: O gabinete de curiosidades de Nassau. Campinas, Brazil: Editora da Unicamp, 2014.

Good recent study on the cabinet of curiosities assembled by Johan Maurits in Recife. Examines how the count assembled the collection, and how its gradual dismantling was part of a careful strategy of gift exchange which did not deliver as much as the former governor of Brazil would have hoped.

- So weit der Erdkreis reicht: Johann Moritz von Nassau-Siegen, 1604-1679. Cleves, Germany: Städtisches Museum, 1979.

Rich volume of essays published to accompany an exhibition in the city museum of Cleves where Johan Maurits resided for the last thirty years of his life. Twenty-six often high-quality articles (all in German), with many illustrations, connect Johan Maurits's Brazilian tenure to his court in Cleves. Too often neglected by scholars of Dutch Brazil.

- van den Boogaart, Ernst, et al., eds. Johan Maurits van Nassau-Siegen, 1604-1679: A Humanist Prince in Europe and Brazil. The Hague: Johan Maurits van Nassau Stichting, 1979.

Strong collection of essays written by leading scholars on the many facets of Johan Maurits's life and career as a German nobleman, governor of Dutch Brazil, and stadtholder of Cleves. With plenty of attention to art and science.

\section{Religion and Tolerance}

One of the key traits of Dutch Brazil was the religious toleration extended to non-Protestant groups, albeit for pragmatic rather than ideological reasons. Many of the colony's inhabitants were practicing Roman Catholics, while the sugar trade could not flourish without the transnational connections of Sephardic Jews who in 1636 were allowed to build the first synagogue in the western hemisphere in Recife. The lack of orthodoxy was a source of disappointment for the Calvinist clergy who had hoped for a truly Protestant settlement in the Americas. Schalkwijk 1998 meticulously charts the normative activities of the public church, as well as its unsuccessful missionary endeavors. The lack of missionary zeal, and its Atlantic implications, are explored in Haefeli 2014. Most literature focuses on the position of the New Christians and Sephardim. Several essays in Bernardini and Fiering 2001give a good impression of the unique opportunities Dutch Brazil offered to Jews. Feitler 2009provides a useful summary, while Gonsalves de Mello 1989 takes a longue durée approach. Several essays in Israel 1997 offer important geopolitical context, while Israel and Schwartz 2007 provides two different takes on toleration in 17th-century Brazil. Both reveal that the position of Catholics in Dutch Brazil was ambiguous. Schwartz 2008 is an outstanding monograph on the various guises of toleration within the Iberian orbit, while Volume 5 of Leite 1938- 
1950 offers many details on Dutch Brazil from the perspective of the Jesuits, an often neglected view in the colony's historiography.

- Bernardini, Paolo, and Norman Fiering, eds. The Jews and the Expansion of Europe to the West, 1450-1800. New York: Berghahn, 2001.

Outstanding collection of essays with contributions by several major scholars. The essays by Schmidt, Israel, and Klooster focus specifically on Dutch Brazil, but many of the other contributions (Seymour Drescher's most notably) also refer to the position of Jews in Dutch Recife, hence contextualizing and broadening the scope of the colony in Atlantic history.

- Feitler, Bruno. "Jews and New Christians in Dutch Brazil, 1630-1654." In Atlantic Diasporas: Jews, Conversos, and Crypto-Jews in the Age of Mercantilism, 1500-1800. Edited by Richard L. Kagan and Philip D. Morgan, 123-151. Baltimore: Johns Hopkins University Press, 2009.

The most accessible recent overview of the position of Jews and New Christians in Dutch Brazil. Focuses on the fluid and flexible identities of the Sephardic community in Brazil during the era of relative religious liberty in Pernambuco, and the internal conflicts of the Portuguese nation over religious issues.

- Gonsalves de Mello, José Antonio. Gente da Nação: Cristaos-novos e judeus em Pernambuco, 1543-1654. Recife, Brazil: Fundação Joaquim Nabuco, 1989.

Study in two parts emphasizing the continuity of (crypto-)Jewish and New Christian life in the northeast before and during the time of Dutch rule in Brazil. Includes an extensive prosopographic appendix with references to primary sources where individual Sephardim are mentioned.

- Haefeli, Evan. "Breaking the Christian Atlantic: The Legacy of Dutch Tolerance in Brazil." In The Legacy of Dutch Brazil. Edited by Michiel van Groesen, 124-145. New York: Cambridge University Press, 2014.

DOI: $10.1017 /$ СВ09781107447776.009

Provides a sweeping argument that Dutch Brazil marked the turning point for European proselytizing efforts in the Atlantic world, with specific attention for two groups of dissenters that the Dutch did not or not very actively attempted to convert-Sephardic Jews and African slaves.

- Israel, Jonathan. Conflicts of Empires: Spain, the Low Countries, and the Struggle for World Supremacy. London: Hambledon, 1997.

Collection of essays on geopolitical relations between Spain and the Netherlands in the 17th century. Three articles focus specifically on the role of Jews and New Christians in political discussion on Brazil in the Dutch Republic and Portugal, while some of the other fifteen provide important context to the conflict over Pernambuco.

- Israel, Jonathan, and Stuart B. Schwartz. The Expansion of Tolerance: Religion in Dutch Brazil. Amsterdam: Amsterdam University Press, 2007.

DOI: 10.5117/9789053569023

Short, pamphlet-sized publication of two 2004 lectures held in Amsterdam. Israel focuses on the possibilities and restrictions of toleration in Dutch Brazil, Schwartz opts for a somewhat broader view, which ended up being one of the components of Schwartz 2008. Here, however, Schwartz provides a little more detail on Dutch Brazil specifically.

\section{- Leite, Serafim. História da Companhia de Jesus no Brasil. 10 vols. Lisbon, Portugal: Livraria Portugalia, $1938-1950$.}

Ten-volume compendium examining the history of the Jesuits in Brazil. Volume 5 deals extensively with the problems Roman Catholicism encountered after the arrival of the Dutch. Hardly used by scholars of Dutch Brazil, despite its different perspective on the colony. 
- Schalkwijk, Frans L. The Reformed Church in Dutch Brazil (1630-1654). Zoetermeer, The Netherlands: Boekencentrum, 1998.

Exhaustive study of the public church in Dutch Brazil. Despite its lack of a clear narrative, this study written by a Reformed missionary (which first appeared as Igreja e Estado no Brasil Holandês, 1986) contains many archival gems and is core reading for anyone interested in religious aspects of the history of Dutch Brazil, including those interested in toleration.

- Schwartz, Stuart B. All Can Be Saved: Religious Tolerance and Salvation in the Iberian Atlantic World. New Haven, CT: Yale University Press, 2008.

Lucid, prize-winning book on the individual quest for salvation in Habsburg Spain, Portugal, and Brazil despite the authorities' efforts to enforce confessional orthodoxy. Provides many useful reminders to scholars of Dutch Brazil that religious toleration came in various sizes and shapes, and was not unique to Recife under Dutch rule.

\section{Art, Architecture, and Science}

One of the most lasting achievements of Dutch Brazil, and more specifically the patronage of Johan Maurits, is the artistic and scientific output the colony generated. Best known outside the circle of specialists are the oil paintings by the Haarlem landscape painter Frans Post, and his colleague Albert Eckhout who painted "ethnographic portraits" of the various ethnicities who lived and worked in Dutch Brazil under Johan Maurits's control. Yet the count's cultural program also comprised an observatory, a menagerie, and a collection of curiosities. The complete set of Post's 155 remaining paintings, as well as sketches he made in Brazil, are the subject of Correa do Lago and Correa do Lago 2007, although De Bruin 2016 presents a recently discovered addition to the artist's oeuvre. Parker Brienen 2006 is the best and most complete study on Albert Eckhout's representations of mestizos, Tupi and Tapuya Indians, and enslaved Africans in Dutch Brazil, while Parker Brienen 2010 is a comprehensive catalogue of Eckhout's modest oeuvre. Whitehead and Boeseman 1989displays the breadth of Johan Maurits's courtly culture, showcasing the connections between art and science. The same could be said for Zandvliet 2002, which offers a broad perspective on colonial maps from the Dutch Golden Age. Van Nederveen Meerkerk 1989 outlines the Dutch influence on architecture and street patterns in Recife, while Hefting 2010 offers a short introduction to military architecture in northeast Brazil.

- Correa do Lago, Pedro, and Bia Correa do Lago. Frans Post (1612-1680): Catalogue Raisonné. Milan: 5 Continents Editions, 2007.

Monumental catalogue of Frans Post's oeuvre, both paintings and drawings. The authors show the development of Post's 155 surviving Brazilian paintings from sober and naturalistic-during his time in Brazil-to colorful and exotic in the latter stages of his career. Indispensable for anyone working on early Brazilian nature, culture, and art.

\section{- $\quad$ de Bruin, Alexander. “Frans Post: Animals in Brazil.” Master Drawings 54.3 (2016): 292-368.}

Report of a recent find of thirty-four drawings of animals made in Brazil by Frans Post, contextualized in exemplary fashion by a senior curator of the Noord-Hollands Archief where the material was discovered. Accompanied a small exhibition on Post and Brazilian zoology in the Rijksmuseum.

- Hefting, Oscar F. "High versus Low: Portuguese and Dutch Fortification Traditions Meet in Colonial Brazil (15001654)." In First Forts: Essays on the Archaeology of Proto-Colonial Fortifications. Edited by Eric Klingelhofer, 189208. Leiden, The Netherlands: Brill, 2010.

DOI: 10.1163/ej.9789004187542.i-278.76

Survey of Dutch military architecture in Brazil, based on archaeological evidence. Discusses several of the remaining fortresses the Dutch built in northeast Brazil, many of which have been substantially renovated or changed since the mid17 th century. 
- $\quad$ Parker Brienen, Rebecca. Visions of Savage Paradise: Albert Eckhout, Court Painter in Colonial Dutch Brazil. Amsterdam: Amsterdam University Press, 2006.

The best and most complete monograph to date of Eckhout's Brazilian paintings, arguing that the cycle of portraits and still-lives were meant to be put on display in Johan Maurits's palace Vrijburg in Mauritsstad. With thorough yet subtle examinations of the eight ethnographic portraits Eckhout made of the non-European inhabitants of Dutch Brazil.

- Parker Brienen, Rebecca. Albert Eckhout: Visões do Paraíso Selvagem - Obra Completa. Rio de Janeiro, Brazil: Editora Capivara, 2010.

Definitive catalogue of the paintings and drawings of people and the natural world by Albert Eckhout. Expertly described and interpreted by the leading authority on Eckhout's paintings of Dutch Brazil.

- van Nederveen Meerkerk, Hannadea. Recife: The Rise of a 17th-Century Trade City from a Cultural-Historical Perspective. Assen, The Netherlands: Van Gorcum, 1989.

Spatial history avant-la-lettre of Dutch Recife and Mauritsstad. Old-fashioned but still very valuable for scholars interested in Dutch colonial architecture and Dutch culture more broadly. With extensive lists of civic and military buildings refurbished or newly built by the Dutch.

- Whitehead, Peter J., and Marinus Boeseman. A Portrait of Dutch 17th-Century Brazil: Animals, Plants and People by the Artists of Johan Maurits of Nassau. Amsterdam: North-Holland, 1989.

Groundbreaking study of the visual culture of Dutch Brazil, with an emphasis on scientific illustrations made by artists in the service of Johan Maurits. Presents for the first time the collection of loose sheets preserved in the Jagellonian Library, Krakow (Libri Picturati). Still one of the best departure points for an examination of Johan Maurits's court culture in Recife. Translated into Portuguese (Um retrato do Brasil holandês do século XVII: animais, plantas e gente pelos artistas de Johan Maurits de Nassau, 1989).

- Zandvliet, Kees. Mapping for Money: Maps, Plans and Topographic Paintings and Their Role in Dutch Overseas Expansion during the 16th and 17th Centuries. Amsterdam: Batavian Lion, 2002.

Wide-ranging study of Dutch 17th-century cartography, with considerable attention on Dutch Brazil and the Dutch Atlantic world more broadly. Originally a PhD dissertation, this book distinguishes itself favorably from traditional cartographic studies by its systematic comparison of maps and handwritten sources.

\section{Legacy}

As Schwartz 1991 demonstrates, Dutch Brazil added to already existing tensions between Madrid and Lisbon during the Union of the Crowns, partly explaining the raison d'être of the West India Company. The failure of Admiral Witte de With to save the colony in the late 1640s, described in great detail by Van Hoboken 1955, heralded the downfall of Recife. The immediate legacy of Dutch Brazil after the fall of Recife in 1654 was one of drawn-out political negotiations between the Dutch Republic and Portugal which lasted until 1669 and which is the subject of both Van de Haar 1961, which covers the basics very well, and Cabral de Mello 1998, which is the definitive account of 17th-century Luso-Dutch diplomacy. In Brazil, Portuguese control was restored by leaders who had fought the Dutch, as Boxer 1952 describes in vivid detail. Van Groesen 2014 surveys the many different legacies of Dutch Brazil in the Atlantic world, and elaborates on the Brazilian mythologizing of the colony that is the subject of Cabral de Mello 1986. Schmidt 2015 charts the appeal of exoticism in the Dutch Republic from the later 17th century onward, which occasionally includes visual reminders of Brazil, while the contributions in Oostindie and Roitman 2014 explore what happened to Dutch Atlantic trade after the memory of Brazil had receded.

- Boxer, Charles R. Salvador de Sá and the Struggle for Brazil and Angola, 1602-86. London: Athlone, 1952.

Classic study, essentially a biography of Salvador de Sá, who fought the Dutch in Salvador and several decades later ousted 
the West India Company from Sao Tomé and Angola. After the fall of Dutch Brazil, he would go on to become governor of Rio de Janeiro and Angola.

- Cabral de Mello, Evaldo. Rubro veio: O imaginário da restauração Pernambucana. Rio de Janeiro, Brazil: Editora Nova Fronteira, 1986.

Arguably the author's finest and most original piece of scholarship, charting and examining various forms of nativist mythologies which survived in northeast Brazil. Focuses specifically on the long-term impact of the overthrow of the Dutch regime on regional and national collective identities.

- Cabral de Mello, Evaldo. O negócio do Brasil: Portugal, os Países Baixos e o Nordeste, 1641-1669. Rio de Janeiro, Brazil: Topbooks, 1998.

Important book on the souring of diplomatic relations between Portugal and the United Provinces over the issue of Brazil. Traces the diplomatic (and occasionally violent) conflict until a settlement of retribution payments for the Dutch loss of Brazil was reached in 1669, and places these negotiations in a broader pan-European context. Translated into Dutch (as De Braziliaanse affaire) in 2005.

- Oostindie, Gert, and Jessica V. Roitman, eds. Dutch Atlantic Connections, 1680-1800: Linking Empires, Bridging Borders. Leiden, The Netherlands: Brill, 2014.

Introduction and fourteen essays focusing on the Dutch Atlantic after the demise of Dutch Brazil, with an emphasis on mercantile networks, and the transformation of traders from the Dutch Republic from empire builders to traffickers and middlemen.

- Schmidt, Benjamin. Inventing Exoticism: Geography, Globalism, and Europe's Early Modern World. Philadelphia: University of Pennsylvania Press, 2015.

Sweeping study of the afterlife of Dutch images of the non-European world in the later 17th and 18th centuries, centered around the concept of exoticism. Schmidt demonstrates how various colonies in the Dutch realm were conflated in visual culture, and studies the concept of the transmediation of images from one genre to another.

- Schwartz, Stuart B. “'The Voyage of the Vassals': Royal Power, Noble Obligations, and Merchant Capital Before the Portuguese Restoration of Independence, 1624-1640." The American Historical Review 96.3 (1991): 735-762.

DOI: $10.2307 / 2162429$

Imaginative article on Iberian political maneuvering in the second quarter of the 17th century. Implies that the Dutch attack on Salvador in 1624 helped set the Portuguese on the path to their struggle for independence which began in 1640, and thus underlines the broader geopolitical impact of the colony.

- van de Haar, Cornelis. De diplomatieke betrekkingen tussen de Republiek en Portugal, 1640-1661. Groningen, The Netherlands: Wolters, 1961.

Concise study of diplomatic relations between the Dutch Republic and Restoration Portugal, focusing on the fallout of the planters' revolt in Brazil. Provides a very useful examination of the pamphlet war on the future of Dutch Brazil in the second half of the 1640s.

- $\quad$ van Groesen, Michiel, ed. The Legacy of Dutch Brazil. New York: Cambridge University Press, 2014.

Twelve essays, an introduction, and an epilogue devoted to the theme of the multiple legacies of Dutch Brazil, with specialized contributions on the colony's geopolitical and cultural legacies in the early modern Atlantic world, and the carefully constructed memories and myths of the colony in both the Netherlands and Brazil in the 19th and 20th centuries. 
- $\quad$ van Hoboken, Willem J. Witte de With in Brazilië, 1648-1649. Amsterdam: Noord-Hollandsche Uitgevers Maatschappij, 1955.

Old-fashioned yet very detailed study of a major expedition designed to reverse the decline of Dutch fortunes in Brazil. Van Hoboken demonstrates that Witte de With failed through a combination of misfortune and internal bickering in Recife over military and naval strategy. 